\title{
HIV prevention program for young urban women in post-conflict
} Liberia

\author{
Ernree Muku Bee*, Ernlee M Barbu, Wede M Nagbe, Oretha Perry, \\ Wede Seekey, Monica Quaqua, Mawen Gobeh, Diasajou Woods, \\ Fulton Shannon, Stephen B Kennedy and Pearl Fahnbulleh
}

Address: UL-PIRE Africa Center, An HIV/AIDS Research Center, A. M. Dogliotti College of Medicine, University of Liberia, Monrovia, Liberia

* Corresponding author

from Frontiers of Retrovirology: Complex retroviruses, retroelements and their hosts

Montpellier, France. 2I-23 September 2009

Published: 24 September 2009

Retrovirology 2009, 6(Suppl 2):P9 doi:10.1 I86/1742-4690-6-S2-P9

This abstract is available from: http://www.retrovirology.com/content/6/S2/P9

(C) 2009 Bee et al; licensee BioMed Central Ltd.

\section{Background}

Young women account for an increasing prevalence of HIV/STDs in Sub-Saharan Africa, including Liberia. Despite being a vulnerable population, there is a significant need for women in post-conflict settings, like Liberia, to be used as stakeholders for gender-based program development in the mitigation of HIV/AIDS.

\section{Methods}

Thirty-nine (39) women aged 18-29 years and ten (10) recognized female key informants, recruited from the local community and international organizations, were interviewed by qualitative methods to ascertain their HIV risk behaviors and perceptions regarding the development and implementation of a gender-based HIV prevention program for young women in post-conflict Liberia. The qualitative interviews were audiotaped, transcribed and analyzed for common themes.

\section{Results}

Young women in post-conflict settings, like Liberia, are highly susceptible to HIV/STDs from domestic and gender-based violence, psychosocial inequality, household protection, economic and gender-based inequity, and the lack of gender-focused empowerment programs.

\section{Conclusion}

Gender-based HIV/STD-related programs, like Sisters Informing Sisters About Topics on AIDS (SISTA), can be culturally adapted to empower young women, as well as mitigate the spread of HIV/STDs in post-conflict settings, like Liberia.

\section{Acknowledgements}

Support for this project was provided by the Corporate Development Fund (CDF) of the Pacific Institute for Research \& Evaluation (PIRE). Additional contributions were provided by grants [ROI HD 045 I 33 and R2I MH 082666] from the National Institute of Child Health and Human Development (NICHD) and the National Institute of Mental Health (NIMH) of the National Institutes of Health (NIH) in Bethesda, Maryland, USA. 